Psychological Medicine, 1997, 27, 505-508. Copyright (C) 1997 Cambridge University Press

\title{
EDITORIAL
}

\section{Ill fitting genes: the biology of weight and shape control in relation to body composition and eating disorders ${ }^{1}$}

There are strong moral overtones associated with eating behaviour and with this goes the contemporary assumption that anyone can choose their shape and weight if only they try hard enough. Arguably, it is this false gospel that has led to the recent increase in bulimia nervosa (BN). Women struggling to attain an idealized shape have drastically to subvert their bodies' homeostatic mechanisms: the battle is rarely won and eventually, the victim turns for help to escape the scars and trauma. On the other hand, the shimmering vision of anorexia nervosa (AN) appears to support the myth.

Recent advances in our understanding of the biological control of weight and shape have profound implications for our understanding of the aetiology, the prevention and the management of eating disorders and possibly for other psychiatric conditions that alter appetite and weight. These developments may also help us replace the 'slimming industry's' hype with a stronger sense of what, in the long term, is realistically possible.

There are interesting links between bulimia nervosa and obesity. Approximately one-third of cases of bulimic eating disorders in a community study had a family history of obesity and premorbid obesity occurred in 10-20\% of them (Hay et al. 1996). The clinical features of bulimia nervosa suggest that the mechanisms controlling weight and shape are functional in these subjects, and that they are opposed by cognitive control. Anorexia nervosa (AN), on the other hand, is associated with leanness (Hebebrand \& Remschmidt, 1995), with the risk of having a first-degree family member sibling with an eating disorder increased by approximately seven-fold (Treasure \& Holland, 1995). Twin studies also suggest that anorexic traits and the syndrome have a significant genetic component (Rutherford et al. 1993; Treasure \& Holland, 1995). In comparison to bulimia, the clinical features of anorexia nervosa suggest a more profound disturbance in appetite and body weight control (Owen, 1990, 1992; Hebebrand \& Remschmidt, 1995). It is uncertain whether this disturbance is primary (as argued by Treasure \& Campbell, 1994) or is secondary to psychological motivational factors.

Within the last 2 years, substantial advances have been made in the understanding of longer term control of appetite (Bray, 1996, for review). To a considerable extent, this has resulted from the identification and cloning of the ob (obese) gene (the ob mutation is an autosomal recessive mutation that gives rise to a strain of infertile, hyperphagic, obese (ob/ob) mice (Zhang et al. 1994)). The messenger RNA (mRNA) for this gene has only been found in adipose tissue and it encodes leptin which is a 167 amino acid peptide (leptin - from the Greek leptos meaning thin). Injection of leptin into ob/ob mice results in weight loss (up to $40 \% /$ month), increased activity and the normalization of blood insulin and glucose: it also corrects their fertility problems (Chehab et al. 1996). Plasma leptin levels show a linear relationship with fat cell mass (Considine et al. 1995) and body mass index (BMI) (Frederich et al. 1995; Considine et al. 1996a). Leptin expression in rodents varies with nutritional state and is lower in the fasting condition and higher during feeding periods (Saladin et al. 1995). Findings such as those, support a 'lipostat or adipostat model' of weight regulation which, in essence, postulates that the relative stability of weight over long periods is related to body fat content (Weigle et al. 1995). It is also apparent that in such a model, a defective 'lipostat' system is likely to produce a vulnerability to weight and appetite related pathology.

${ }^{1}$ Address for correspondence: Dr Janet Treasure, Institute of Psychiatry, De Crespigny Park, London SE5 8AF. 
Saladin et al. (1995) have shown that ob mRNA levels in rats shows a diurnal variation, increasing during the night (after rats start feeding), and decreasing during the day. Fasting abolishes these changes, but a single injection of insulin increases the mRNA to a 'fed' level of expression. There also appears to be a close association between hyperleptinaemia and hyperinsulinaemia suggesting that the pancreas and adipose tissue function in synchrony and that a 'lipostat model' which solely involves leptin in a direct feedback loop is probably over-simplistic.

Circulating leptin binds to receptors in the choroid plexus and enters the brain by a saturable process (Banks et al. 1996). The receptor for leptin has now been cloned and shown to be part of the cytokine superfamily (Tartaglia et al. 1995). This receptor is abnormal in another mutant mouse, the diabetic (db/db) mouse, which has a similar phenotype to the ob/ob mouse (Lee et al. 1996). This is what would be predicted, i.e. a mutation in any part of the 'leptin loop' would be likely to produce an abnormal phenotype.

In the central nervous system, neuropeptide (NPY), which is present in the paraventricular nucleus (PVN) and ventromedial hypothalamus (VMH), is a powerful stimulant of food intake by a mechanism which involves neuropeptide Y5 receptors (Gerald et al. 1996). NPY rises as rats start their nightly feeding cycle and declines as feeding continues. Stephens et al. (1995) have demonstrated that in mice, leptin treatment normalizes the elevated levels of NPY mRNA, which are present in the hypothalamus of the ob/ob mouse, and thus, it appears that leptin's feedback loop from adipocytes to the CNS is at least partially mediated by NPY in the hypothalamus. This idea is further supported by the observation that ob mRNA is increased in the adipose tissue of rats in which the ventromedial hypothalamus (VMH) had been lesioned (Funahashi et al. 1995).

Several studies (Hamilton et al. 1995; Lonnquist et al. 1995; Maffei et al. 1995) have measured the expression of ob mRNA in adipose tissue and report a good correlation between BMI, ob gene expression and leptin levels and, to date, no mutations in the leptin gene have been found in humans (Considine et al. 1995, 1996b). The concentration of leptin in the peripheral circulation is reported to be approximately four-fold higher in obese compared to lean individuals (Considine et al. 1996a). One possible explanation is that most obese humans are relatively resistant to leptin. The most obvious explanation for this would be that there is an inherent problem with the leptin receptor or with its coupled signal transduction process. In this context however, it is interesting to note that cerebrospinal fluid (CSF) levels of leptin in obese subjects are only $30 \%$ higher than in those that are lean and there is a negative correlation between the CSF/serum leptin ratio and BMI. This, therefore, raises the possibility that in humans, the leptin transporter protein into the hypothalamus may be a limiting step in the 'loop' and its dysfunction may be of aetiological significance in eating disorders (Caro et al. 1996).

Another feature of leptin which Bray (1996) has highlighted, is its role in reproduction. Adrenalectomy of the ob/ob mouse restores most of the metabolic abnormalities but unlike the administration of leptin, it does not correct the infertility (Bray \& York, 1979). Bray suggests that 'leptin, by modulating oestrogen expression may serve as a signal from fat to the brain about the adequacy of fat stores for reproduction'. This is, of course, germane to eating disorders as both anorexia nervosa and bulimia nervosa patients have abnormal reproductive function. On the other hand, the clinical features of anorexia nervosa, hyperactivity, increased energy expenditure and weight loss, resemble the effects of exogenous leptin administration. In a small preliminary study in anorexia nervosa, Hebebrand et al. (1995) measured plasma leptin levels in underweight patients, and found that they were in the normal range in 5/15 (in the other 10 subjects, the levels were undetectable). These authors did not find any clinical features which could account for the unexpected finding that leptin levels were within the normal range in some cases of severe emaciation. These data are interesting in that they suggest that there may be a physiological/ psychological mechanism that discourages weight gain in some patients with anorexia nervosa. On the other hand, plasma leptin levels are normal in patients who have recovered from anorexia nervosa (Brown et al. 1996). If there are abnormalities in the 'leptin loop' in some subjects suffering from eating disorders, it is possible that they will only be detected in studies where the system is 'challenged', for example, in a protocol in which the leptin response to 24 hours of fasting is 
assessed. However, given the clinical state of subjects suffering from anorexia nervosa, this may not be particularly easy. Interestingly, however, in a recent study with mice in which fasting was used as a 'challenge' to the leptin system, Ahima et al. (1996) observed that preventing a starvation induced fall in leptin by the administration of exogenous leptin, led to a blunting of many of the neuroendocrine sequelae of starvation but had no effect on body weight or blood glucose: they have proposed that the primary physiological role of leptin may be related to endocrine function. This remains to be confirmed in mice and whether leptin has the same role in humans is unclear.

There are strong genetic influences on weight and shape. Twin studies suggest that $70 \%$ of the variation in body mass index (BMI) is genetic whereas adoption studies indicate a heritability of around 30\% (e.g. Price \& Gottesman, 1991). The distribution of subcutaneous fat is also subject to genetic factors. Obesity, therefore, appears to be a complex multifactorial trait involving social, environmental and genetic factors, with the possibility of a major gene effect operating on a polygenic-multifactorial background (Bouchard, 1995). All of these factors account for the variability of body weight and shape both within and between different ethnic human populations. Without this inter-individual variation, evolutionary and adaptive changes in the physiology of food intake, for example, by adaptation to different diets and climates, would not be possible. The negative aspect of this is that a particular genetic background may be poorly adapted to the prevailing environmental or social conditions and hence may predispose an individual to an eating disorder. Thus, for example, it can be hypothesized that patients with bulimia nervosa who have a strong family history of obesity may have inherited a defect in the 'leptin loop', e.g. in their leptin receptors. Dieting and loss of fat cells may then lead to a reduction in central leptin which in turn allows NPY levels to rise with a resultant overwhelming hunger and binging. In contrast, patients with anorexia nervosa may have a predisposition to dysfunctional NPY receptors which predisposes them to lose weight in the context of psychosocial stress. It is interesting that consumer demand for lean meat with selective breeding of lean strains such as the European hybrid pig is associated with the emergence in pigs of a condition that resembles anorexia nervosa, so called 'thin sow disease' (Treasure \& Owen, 1997). The families of patients with anorexia nervosa have a disposition to leanness and AN itself may represent an extreme variant of body composition (Hebebrand \& Remschmidt, 1995). These various observations support the notion that susceptibility to anorexia nervosa is at least partly related to genetically defined body types. The study of the molecular genetics of these conditions and of general weight and body shape has the potential to realize a better understanding of their pathophysiology.

J. TREASURE, D. COLLIER AND I. C. CAMPBELL

Our leptin studies quoted in this study (Brown et al. 1996) were supported by a grant from the Wellcome Trust.

\section{REFERENCES}

Ahima, R. S., Prabakaran, D., Mantzoros, C., Daqing, Q., Bradford, L., Maratos-Flier, E. \& Flier, J. S. (1996). Role of leptin in the neuroendocrine response to fasting. Nature 382, 250-252.

Banks, W. A., Kastin, A. J., Huang, W. T., Jaspan, J. D. \& Maness, L. M. (1996). Leptin enters the brain by a saturable system independent of insulin. Peptides 17, 305-311.

Bouchard, C. (1995). Genetic influences on body weight and shape. In Eating Disorders and Obesity. A Comprehensive Handbook (ed. K. D. Brownell and C. G. Fairburn), pp. 21-26. Guilford: New York.

Brown, N., Ward, A., Treasure, J., Campbell, I. C., Tiller, J., Caro, J. \& Surwit, R. (1996). Leptin levels in anorexia nervosa (acute and long term recovered). International Journal of Obesity 20, 37.

Bray, G. A. (1996). Leptin and leptinomania. Lancet 348, 140-141.

Bray, G. A. \& York, D. A. (1979). Hypothalamic and genetic obesity in experimental animals: an autonomic and endocrine hypothesis. Physiological Reviews 59, 719-809.

Caro, J. F., Kolaczynski, J. W., Nyce, M. R., Ohannesian, J. P.,
Opentanoval, I., Goldman, W. H., Lynn, R. B., Zhang, P., Sinha, M. K. \& Considine, R. V. (1996). Decreased cerebrospinalfluid/serum leptin ratio in obesity: a possible mechanism for leptin resistance. Lancet 348, 159-161.

Chehab, F. F., Lim, M. E. \& Lu, R. (1996). Correction of the sterility defect in homozygous obese female mice by treatment with human recombinant leptin. Nature (Genetics) 12, 318-320.

Considine, R. V., Considine, E. L., Williams, C. J., Nyce, M. R., Magosin, S. A., Bauer, T. L., Rosato, E. L., Colberg, J. \& Caro, J. F. (1995). Evidence against either a premature stop codon or the absence of obese gene mRNA in human obesity. Journal of Clinical Investigation 95, 2986-2988.

Considine, R. V., Sinha, M. K., Heiman, M. L., Kriagiunas, A., Stephens, T. W., Nyce, M. R., Ohannesian, J. P., Marco, C. C., McKee, L. J., Bauer, T. L. \& Caro, J. F. (1996a). Serum immunoreactive leptin concentrations in normal weight and obese humans. New England Journal of Medicine 334, 292-295.

Considine, R. V., Considine, E. L. \& Williams, C. J. (1996b). Mutation screening and identification of a sequence variation in the human ob gene coding region. Biochemical Biophysical Research Communications 220, 735-739. 
Frederich, R. C., Hamaan, A., Anderson, S., Lollman, B., Lowell, B. B. \& Flier, J. S. (1995). Leptin levels reflect body lipid content in mice: evidence for diet-induced resistance to leptin action. Nature Medicine 1, 1311-1344.

Funahashi, T., Shimomura, I., Hiraoka, H., Arai, T., Takahashi, M., Nakamura, T., Nozaki, S., Yamashita, S., Takemura, K., Tokunaga, K. \& Matsuzawa, Y. (1995). Enhanced expression of rat obese (ob) gene in adipose tissues of VMH-lesioned rats. Biochemical Biophysical Research Communications 211, 469-475.

Gerald, C., Walker, M. W., Criscione, L., Gustafson, F. I., BatzlHartmann, C., Smith, K. E., Vaysse, P., Durkin, M. M., Laz, T. M., Linemeyer, D. L., Schaffhauser, A. O., Whitebread, S., Hofbauer, K. G., Taber, R. I., Branchek, T. A. \& Weinshank, R. L. (1996). A receptor subtype involved in neuropeptide $Y$ induced food intake. Nature 382, 168-171.

Hamilton, B. S., Paglia, D., Kwan, A. Y. M. \& Deitel, M. (1995). Increased obese expression in omental fat cells from massively obese humans. Nature Medicine 1, 953-956.

Hay, P. J., Fairburn, C. G. \& Doll, H. A. (1996). The classification of bulimic eating disorders: a community based cluster analysis study. Psychological Medicine 26, 801-812.

Hebebrand, J. \& Remschmidt, H. (1995). Anorexia nervosa viewed as an extreme weight condition: genetic implications. Human Genetics 95, 1-11.

Hebebrand, J., Van der Heydon, J., Devos, R., Kopp, W., Herportz, S., Remschmidt, H. \& Herzog, W. (1995). Plasma concentrations of obese protein in anorexia nervosa. Lancet 346, 1624-1625.

Lee, G. H., Proenca, R., Montez, J. M., Proenca, R., Montez, J. M., Caroll, K. M., Darvishzadeh, J. G., Lee, J. I. \& Friedman, J. M. (1996). Abnormal splicing of the leptin receptor in diabetic mice. Nature 379, 632-635.

Lönnqvist, P., Arner, P., Nordfors, L. \& Schalling, M. (1995). Over expression of the obese (ob) gene in adipose tissue of human obese subjects. Nature Medicine 1, 950-953.

Maffei, M., Hallas, J., Ravussin, E., Pratley, R. E., Lee, G. H., Zhang, Y., Fei, H., Kim, S., Lallone, R., Ranganathan, S., Kern,
P. A. \& Friedman, J. M. (1995). Leptin levels in human and rodent: measurement of plasma leptin and ob mRNA in obese and weight reduced subjects. Nature Medicine 1, 1155-1161.

Owen, J. B. (1990). Weight control and appetite: nature over nurture. Animal Breeding Abstracts 58, 583-591.

Owen, J. B. (1992). Genetic aspects of appetite and feed choice in animals. Journal of Agricultural Science 119, 151-155.

Price, R. A. \& Gottesman, I. I. (1991). Body fat in identical twins reared apart: the roles for genes and environment. Behavioural Genetics 21, 1-7.

Rutherford, J., McGuffin, P., Katz, R. J. \& Murray, R. M. (1993). Genetic influences on eating attitudes in a normal female twin population. Psychological Medicine 23, 425-436.

Saladin, R., Devos, P., Guerre-Millo, M., Leturque, A., Girard, J., Staels, B. \& Auwerx, J., Hoffman, J., Hsiung, H. M., Kriauciunas, A., Mackelber, N., Rosteck, P. R., Schoner, B., Smith, D., Tinsley, F. C., Zhang, X. Y. \& Heiman, M. (1995). Transient expression in obese gene expression after food intake or administration. Nature 377, 527-529.

Stephens, T. W., Basinski, M., Bristow, P. K., Bue-Valleskey, J. M., Burgett, S. G., Craft, L. \& Hale, J. (1995). The role of neuropeptide $\mathrm{Y}$ in the anti obesity action of the obese gene product. Nature 377, 530-532.

Tartaglia, L. A., Dembski, M. \& Weng, X. (1995). Identification and expression cloning of a leptin receptor, OB-R. Cell 83, 1263-1271. Treasure, J. L. \& Campbell, I. C. (1994). The case of biology in the aetiology of anorexia nervosa. Psychological Medicine 24, 3-8.

Treasure, J. L. \& Holland, A. (1995). Genetic factors in eating disorders. In Handbook of Eating Disorders (ed. G. Szmukler, C. Dare and J. L. Treasure), pp. 65-82. Wiley: Chichester.

Treasure, J. L. \& Owen, J. B. (1997). Intriguing links between animal behaviour and anorexia nervosa. International Journal of Eating Disorders (in the press).

Zhang, Y., Proenca, R., Maffei, M., Barone, M., Leopold, L. \& Friedman, J. M. (1994). Positional cloning of the mouse obese gene and its human homologue. Nature 372, 425-432. 